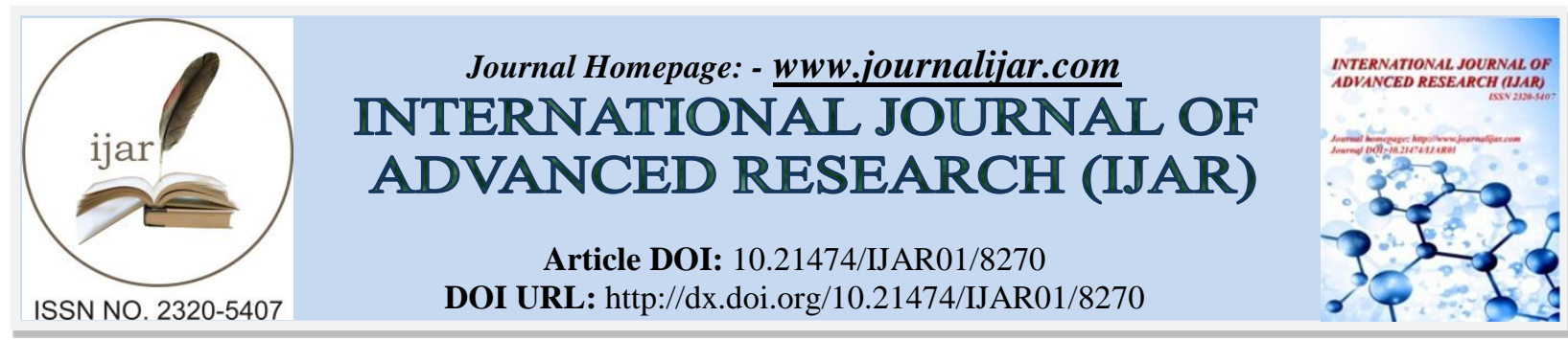

RESEARCH ARTICLE

\title{
MINERALS PROFILE AND PROXIMATE ANALYSIS IN SOME COMMONLY CONSUMED VEGETABLES IN KHARTOUM.
}

Ibrahim M. Said ${ }^{1}$, Hseeba A. Saad ${ }^{1}$ and Shama I. Y. Adam ${ }^{2}$.

1. Department of Zoology, Biochemistry, University of Khartoum, Faculty of Science.

2. Department of Biochemistry, Faculty of Sciences and Technology, University of Al-Neelain.

\section{Manuscript Info}

Manuscript History

Received: 20 October 2018

Final Accepted: 22 November 2018

Published: December 2018

\section{Keywords:}

magnesium, iron, copper, zinc, vegetables, proximate analysis, moisture $\%$, Organic content $\%$ and ash content $\%$.

\section{Abstract}

This study was carried out to evaluate mineral profile and chemical composition of seven Sudanese vegetables Tomato (Lycopersicon esculentum Mill.), Snake cucumber (Cucumis melo var. flexuosus), Cucumber (Cucumis sativus), Carrot (Daucus carota subsp. Sativus), Bell pepper (Capsicum annuum), Garden rocket (Eruca sativa) and Parsley (Apium petroselinum). Samples were collected in august 2016 from different markets in Khartoum State - Sudan. Tissues of collected samples were cleaned by tap water and distilled water, then dried, and coarsely powdered and pulverized with a mortar. The essential elements $(\mathrm{Mg}, \mathrm{Fe}, \mathrm{Cu}$ and $\mathrm{Zn}$ ) were investigated using Atomic Absorption Spectrophotometer (FAAS). In addition proximate analyses of moisture, organic content and ash content were conducted as described by the Association of Official Analytical Chemists (AOAC, 2007). Vegetable samples revealed significant variations in mineral contents and proximate analysis. Zinc concentrations ranged between $(7.56-6.01 \mathrm{mg} / \mathrm{Kg})$, with non-significantly difference in concentration values, which were reported in all seven vegetables. Iron and magnesium concentrations were significantly high in leafy vegetables (Garden rocket and Parsley). Significantly high concentration was reported in Carrot. Values reported for $\mathrm{Fe}, \mathrm{Mg}$ and $\mathrm{Cu}$ concentrations ranged between $(98.67-24.05 \mathrm{mg} / \mathrm{Kg}),(2938.57-1136.07 \mathrm{mg} / \mathrm{Kg})$ and $(3.54-0.95 \mathrm{mg} / \mathrm{Kg})$ respectively. Percentages of moisture, organic content and ash content ranged between (0.33- 0.26\%), (96.11 $95.75 \%)$ and $(3.54-0.95 \mathrm{mg} / \mathrm{Kg})$ respectively. The results showed that almost all vegetables contain appreciable amount of essential nutrients.

Copy Right, IJAR, 2018,. All rights reserved.

\section{Introduction:-}

A vegetable is a plant cultivated for food, especially an edible herb or root used for human consumption (Little et al., 1992). It is not a botanical term, some vegetables botanically are also fruits, but for the reason that the way they are traditionally used and produced they are considered to be vegetables (Gregory, 2015).

Khartoum State considered the highest consumer of vegetables in Sudan that due to the continuous expanding of the population, income level and nutritional awareness (Mohammed, 2005). According to the Joint FAO/WHO Expert 
(2003) Consultation on diet, consumption regular daily sufficient amounts of vegetables can prevent chronic diseases, and it recommended intake of a minimum of $400 \mathrm{~g}$ of fruit and vegetables daily. Vegetables uptake prevent diseases, especially diseases of this age, such as heart diseases and cancer, diabetes and obesity, furtherer more for the prevention of many microelement deficiencies, especially in less developed countries.

Minerals are a valuable or useful chemical substance that is formed naturally in the ground (Dictionary, C., 2008). There are thirteen key minerals to plants. Six of these macronutrients are required in generally higher amounts than others such as magnesium, which constitute altogether between 5 to $10 \%$ of the dry weight of most plants. (Muchukuri et al, 2004). Magnesium is the most dominant intracellular divalent cation, play a wide role in metabolic, structural, and regulatory functions. Mostly complexes with ATP and other molecules with negatively charged moieties, and it is a cofactor for more than 300 enzymes (Wolf and Trapani 2008).

Iron, Zinc, Copper considered as micronutrients that are known to be required by plants, and generally absorbed as divalent ions via divalent ion channels (Welch, 1995). In spite of the fact that the concentration of naturally occurring elements in the environment is generally in small quantities, however they may directly or indirectly influence the chemical nature of food, water and airborne particulates and dust (Singh and Steinnes, 1994).

Iron is important for a wide range of cellular functions. Its capability to simply accept and lose electrons makes it a crucial factor of the energetic site of a huge variety of enzymes, and in the oxygen-carrying proteins hemoglobin and myoglobin. Fe also can be toxic if present in excess as it is able to catalyze the production of reactive oxygen species via the Fenton and Haber-Weiss reactions. Since of this dual nature, essential but toxic, homeostatic processes maintain cellular and body iron levels within strict physiological limits (Crichton, 2016).

Copper is a catalytic metallic, micronutrient, essential in its actions to permit the system to cope with iron. Many research have linked copper in animals and humans with the synthesis of neurotransmitters, pituitary hormones, biopigments, and the establishment of a firm connective tissue network, functions which are manifested through copper-dependent enzymes. Copper in flora in constrained especially to the photosynthetic system of the plant.

The physical and chemical properties of Copper permit it to serve as an enzyme cofactor, as an oxygen activator, and as an essential factor in iron (Edward and Harris, 2013).

Zinc is a part of about 3,000 human proteins. In these proteins, zinc has a catalytic, structural, or regulatory function. The coordination environments of zinc in proteins have been categorized. Zinc enzymes take place in all six enzyme classes, the largest group of zinc enzymes are proteinases (Auld, 2005). Zinc overload can be a precursor for cell death and subsequent brain degeneration following a stroke. Zinc mediates cell death by causing mitochondrial dysfunction, by reinforcing apoptotic signaling cascades, and by inhibiting neuronal metabolism (Li, 2012). Zinc deficiency in human populations throughout the world is widespread, and it may affect nearly two billion subjects. Zinc deficiency should be present in countries where primarily cereal proteins are consumed by the population. There is a spectrum of zinc deficiency, ranging from severe cases to marginally deficient, in any population (Prasad, 2013).

Vegetables contain and accumulate many elements in their edible and non edible parts. Data concerning the concentration and distribution of these elements in different environmental ecosystems is very important for the general assessments of these environmental components, and for the need to public concern response about the impacts of chemical accidents and risk of environmental contamination. Such information is also required to assess soil quality for Agricultural and animal production activities. They play a significant role in chemical, biochemical, physiological, metabolic, geochemical and enzymatic process. Therefore, their importance is pronounced on the health and diseases of plants, animals and human being. Consequently the assessment of the nutrient contents of vegetables helps to recognize foods rich in minerals and achieve knowledge on the approaches of appropriate utilization and preparation to improve bioavailability of nutrients. Therefore, the objective of this work was to assess mineral contents (magnesium $(\mathrm{Mg})$, iron $(\mathrm{Fe})$, copper $(\mathrm{Cu})$ and zinc $(\mathrm{Zn})$ ) from different vegetables that are commonly consumed in Khartoum markets. 


\section{Materials And Methods:- \\ Sample Collection}

Vegetable samples Tomato (Lycopersicon esculentum Mill.), Snake cucumber (Cucumis melo var. flexuosus), Cucumber (Cucumis sativus), Carrot (Daucus carota subsp. Sativus), Bell pepper (Capsicum annuum), Garden rocket (Eruca sativa) and Parsley (Apium petroselinum)) were collected in august 2016 from seven markets in Khartoum state.

\section{Preparation of Samples Solutions}

Vegetable samples tissues were cleaned by tap water and distilled water then dried under shade and coarsely powdered and pulverized using mortar. Dried samples $(2 \mathrm{~g})$ were treated with $20 \%$ of conc. hydrochloric acid, heated on hot plate to dissolve then cooled. The solution was filtered through an acid washed filter paper then transferred to $50 \mathrm{ml}$ volumetric flask and diluted to volume with distilled water.

\section{Minerals Contents of Vegetable Samples}

Mineral contents $(\mathrm{Mg}, \mathrm{Fe}, \mathrm{Cu}$ and $\mathrm{Zn})$ of vegetable samples were determined by atomic absorption spectrometry (AAS Device Model Buck 210VGP, U.S.A. 2003).

\section{Proximate Analyses}

The methods that used to determine moisture, ash content, and the Organic content were determined as described by the Association of Official Analytical Chemists (AOAC, 2007).

\section{Statistical Analysis}

Data analyzed as complete randomized design. Analysis of variance (ANOVA) was performed According to procedure described by Gomez and Gomez (1984). Means were test by Spearman correlation test to find out the relationship existing among the proximate analysis items, and the minerals concentrations $(\mathrm{Mg}, \mathrm{Fe}, \mathrm{Zn}$ and $\mathrm{Cu}$ ) from types of vegetables under study.

\section{Results:-}

Mineral composition

Significantly high concentrations of magnesium were reported in Garden rocket $(2938.58 \mathrm{mg} / \mathrm{Kg}$ ), Parsley $(2415.71 \mathrm{mg} / \mathrm{Kg})$ and Tomato $(2178.21 \mathrm{mg} / \mathrm{Kg})$. While significant low of $\mathrm{Mg}$ concentrations were reported in Carrot (1299.64mg/Kg), Snake cucumber $(1291.79 \mathrm{mg} / \mathrm{Kg})$ Cucumber $(1219.00 \mathrm{mg} / \mathrm{Kg})$, and Bell pepper $(1136.07 \mathrm{mg} / \mathrm{Kg})$. The highest concentration of Iron was reported in Garden rocket $(98.67 \mathrm{mg} / \mathrm{Kg})$ followed by Parsley $(70.93 \mathrm{mg} / \mathrm{Kg})$. Significantly low Fe concentrations were reported in Tomato $(38.66 \mathrm{mg} / \mathrm{Kg})$, Bell pepper $(32.64 \mathrm{mg} / \mathrm{Kg})$, Snake cucumber $(32.23 \mathrm{mg} / \mathrm{Kg})$ Carrot $(31.37 \mathrm{mg} / \mathrm{Kg})$ and Cucumber $(24.5 \mathrm{mg} / \mathrm{Kg})$. Zinc concentrations were found to be non-significantly high in Garden rocket $(7.56 \mathrm{mg} / \mathrm{Kg})$ and Carrot $(7.13 \mathrm{mg} / \mathrm{Kg})$. While non-significant low values $\mathrm{Zn}$ concentrations were reported Snake cucumber $(6.85 \mathrm{mg} / \mathrm{Kg})$, Cucumber $(6.61 \mathrm{mg} / \mathrm{Kg})$, Tomato $(6.40 \mathrm{mg} / \mathrm{Kg})$, Parsley $(6.35 \mathrm{mg} / \mathrm{Kg})$ and Bell pepper $(6.01 \mathrm{mg} / \mathrm{Kg})$. Cupper concentrations were non-significantly high in Carrot $(3.54 \mathrm{mg} / \mathrm{Kg})$. Garden rocket $(1.17 \mathrm{mg} / \mathrm{Kg})$, While non-significantly low $\mathrm{Cu}$ concentrations were reported in Tomato $(1.51 \mathrm{mg} / \mathrm{Kg})$, Parsley $(1.36 \mathrm{mg} / \mathrm{Kg})$,Snake cucumber $(1.32 \mathrm{mg} / \mathrm{Kg})$, Bell pepper $(1.09 \mathrm{mg} / \mathrm{Kg})$ and Cucumber $(0.95 \mathrm{mg} / \mathrm{Kg})$ as shown in table (1).

\section{Proximate Analysis:}

Results were presented as (Means \pm STD) in table (2). The highest values of moisture percentages were reported for Tomato $(0.33 \%)$, Bell pepper $(0.31 \%)$ and Garden rocket $(0.30 \%)$. While lower percentages were reported for Cucumber $(0.29 \%)$, Snake cucumber $(0.27 \%)$, Carrot $(0.26 \%)$ and Parsley $(0.26 \%)$ with significant differences. Ash contents of vegetable samples were found to be in the following descending order Bell pepper (4.25\%), Tomato (4.13\%), Garden rocket (4.12\%), Parsley (3.89\%), Cucumber (3.88\%), Snake cucumber (3.81\%) and Carrot (3.78\%) with non-significant differences. Significant variations were reported in the percentages of organic content of vegetable samples. The following values were reported Carrot (96.228\%), Snake cucumber (96.19\%), Cucumber (96.12\%), Parsley (96.11\%), Garden rocket (95.88\%), Tomato (95.87\%) and Bell pepper (95.75\%).

\section{Discussion:-}

In the present study seven vegetables samples (Tomato, Snake cucumber, Cucumber, Carrot, Bell pepper, Garden rocket and Parsley) were investigated for minerals contents $(\mathrm{Mg}, \mathrm{Fe}, \mathrm{Cu}$ and $\mathrm{Zn}$ ) in addition to proximate 
composition (moisture\%, organic content\%, and Ash content\%,). Results showed significant variation in $\mathrm{Mg}, \mathrm{Fe}$, Moisture $\%$ and Organic content $\%$. However, considerable amount of mineral were reported.

Magnesium concentrations in all vegetables in present study were higher than that found in the study of Eissa \& ALAhmary, (2005) in Saudi Arabia. While it was higher for snake melon in Ilelaboye et al., (2009) study in Nigeria. It is clear that the higher concentration of $\mathrm{Mg} \& \mathrm{Fe}$ in leafy vegetables (garden rocket and parsley) this may be due to the presence of $\mathrm{Mg}$ as essential element in chlorophyll structure and the role of $\mathrm{Fe}$ in chlorophyll biosynthesis (Heldt, H. W., 2011; Miller, et al., 1984). However the Mg requirement for optimal plant growth is 1500-3500 mg kg-1 in vegetative parts (Forster, 1980); that means Mg concentrations in the collected vegetables are in the normal range.

Iron concentrations in all vegetables in this study were higher than that of Eissa and AL-Ahmary, (2005) in Saudi Arabia. But were lower in garden rocket and snake melon in Barlas, et al., (2011) in Turkey and Ilelaboye et al., (2009) in Nigeria, studies respectively. However, the normal Fe concentration (> 150 and $<500 \mathrm{~kg}-1 \mathrm{dw}$ ) according to Smith et al., (1984) and Yamauchi (1989) respectively; that means Fe concentrations in the collected vegetables are in the normal range.

Different types of vegetables of current study have higher concentration of Zn compared with the studies of Hussein, \& Bruggeman, (1997) in Egypt, Onianwa, et al., (2001) in Nigeria , Parveen, et al., (2003) in Pakistan, Eissa \& ALAhmary, (2005) in Saudi Arabia. whereas lower than that of Radwan, \& Salama, (2006) in Egypt , Ilelaboye et al., (2009) in nigeria, Barlas, et al., (2011) in Turkey. However, generally Zn In leaves the critical deficiency concentrations are below 15-20 mg Zn Kg-1dw (Marschner, 2011). The Zn concentrations range in studied vegetables between $3.35-11.55 \mathrm{mg} / \mathrm{Kg}$, which mean there is $\mathrm{Zn}$ deficiency in all collected samples of vegetables. Zinc deficiency could be due to highly weathered acid soils and in calcareous soils, where those vegetables were cultivated in Vertisols soil (dark cracking clays), which characterized by clay contents of $60 \%$ or more, are alkaline in $\mathrm{pH}$ and have gypsum and calcium carbonate concretions (Zaroug, 2000). The low availability of $\mathrm{Zn}$ in calıcareous soils of high $\mathrm{pH}$ is mainly due to the adsorption of $\mathrm{Zn}$ to clay or $\mathrm{CaCO} 3$, rather than from the formation of sparingly soluble $\mathrm{Zn}(\mathrm{OH}) 2$ or $\mathrm{ZnCO} 3$ (Trehan and Sekhon, 1977), In addition, $\mathrm{Zn}$ uptake and translocation to the shoot are inhibited by high concentrations of bicarbonate, HCO3- (Dogar and van Hai, 1980).

From previous studies on elemental concentrations in plants, Copper is the lowest concentrations. This is due to the fact that $\mathrm{Cu}$ is found in complexed forms. Copper found as highest concentration in carrot may be due to copper's low mobility relative to other elements in plants. While most of this element appears to remain in root until they senesce; only small amounts may move to young organs (Marschner, 2011).

Copper's concentrations in the different types of vegetables in this study showed higher concentrations compared to previous studies of Onianwa, et al., (2001) in Nigeria and Eissa \& AL-Ahmary, (2005) in Saudi Arabia. Whilst were lower in concentration compared to Radwan and Salama, (2006) in Egypt and Ilelaboye et al., (2009) in Nigeria studies. However, the critical deficiency concentration of $\mathrm{Cu}$ in vegetartive plant parts is generally in the range of (> 5 and $>20 \mathrm{~kg}-1 \mathrm{dw}$ ) (Robson and Reuter, 1981). That means $\mathrm{Cu}$ concentrations in the collected vegetables are in the normal range.

In Correlation study between proximate analysis items (moisture (\%), organic content (\%), and Ash content (\%)), and the different concentrations of minerals $(\mathrm{Mg}, \mathrm{Fe}, \mathrm{Zn}$ and $\mathrm{Cu})$ in the different types of the studied vegetables show the following:

There is a significant high correlation between Magnesium and Iron; because both of them have a role in chlorophyll biosynthesis where as Iron used for chlorophyll formation as well as for the functioning of various iron containing enzymes like Aconitase and/or Ferredoxin which they have an essential role in chlorophyll biosynthesis (Miller, et al., 1984) and $\mathrm{Mg}+2$ is present in the center of the ring as the central atom of the chlorophyll and considered as an essential part of chlorophyll (Heldt, 2011).

There is a significant correlation between Magnesium and Zinc; due to Zn role in proton-pumping activity in the tono 7 plast (vacuole membrane), $\mathrm{Zn}+2$ dependent ( $\mathrm{Zn}$.PPiase) maintains a low $\mathrm{pH}$ inside the vacuole and provides a source of energy for active transport across the membrane against a concentration gradient (Lin and Kao, 1990). 
Excess $\mathrm{Zn}$ triggers disturbances in the waters relations, which affect photosynthesis, and lead also to $\mathrm{Mg}$ and $\mathrm{Fe}$ accumulation (Vassilev, et al., 2011).

There is indirect relationship between Iron and Copper. This may be explained according to Marschner, (2011) the molecu $\neg$ lar responses to $\mathrm{Cu}$ deficiency are increased expression of metal reductases and transporters. In addition prioritizing Copper to essential enzymatic pathways including compensatory increases in FeSOD and MnSOD in place of CuZnSOD (superoxide dismutase). These enzymes catalyze the dismutation of superoxide into oxygen and $\mathrm{H} 2 \mathrm{O}$; and works as a defense against oxidative stress.

\section{Conclusion:-}

The goal of this study was to compare the $\mathrm{Mg}, \mathrm{Fe}, \mathrm{Cu}$ and $\mathrm{Zn}$ contents and evaluate proximate analysis of moisture $(\%)$, organic content $(\%)$, and Ash content (\%), in seven vegetables that are widely consumed by the inhabitants of Khartoum state in Sudan. The Garden rocket (Eruca sativa) showed the highest concentrations of $\mathrm{Mg}, \mathrm{Fe}$ and $\mathrm{Cu}$ in the normal range. The Zinc concentrations in all studied types of vegetables have no significant differences, and all of them have Zinc deficiency. The moisture (\%) was highest in Tomato (Lycopersicon esculentum Mill.), Organic content (\%) was highest in Cucumber (Cucumis sativus), and ash content (\%) was highest in Bell pepper (Capsicum annuum).

\section{Recommendations}

1. Adoption of studies and statistical surveys that must be done by consumer and health organizations, in the field of consumption of nutrition in Sudanese life style (gram of nutrient / person / day).

2. Conduct researches about exposure of consumers and related health risks which known as the provisional tolerable daily intake (PTDI).

3. Study the concentrations of various elements in vegetables in different seasons and document the seasonal variation of minerals concentrations in plants and make comparisons.

4. Make vegetables sampling from the farmers followed by soil's tests in different geographical areas in addition to market's sampling to achieve best practice quality control.

5. Encourage researches on Zinc concentrations, and link it with the public health and immunity.

Table 1:-Comparisons between the concentrations of magnesium, Iron, Zinc and Cupper $(\mathrm{mg} / \mathrm{kg})$ in different types

\begin{tabular}{|c|c|c|c|c|}
\hline $\begin{array}{c}\text { Vegetable } \\
\text { s }\end{array}$ & $\begin{array}{c}\text { Mg (mg/kg) (Mean } \pm \\
\text { STD })\end{array}$ & $\begin{array}{c}\text { Iron }(\mathrm{mg} / \mathrm{kg})(\text { Mean } \\
\pm \text { STD })\end{array}$ & $\begin{array}{c}\text { Zinc (mg/kg) (Mean } \\
\pm \text { STD) }\end{array}$ & $\begin{array}{c}\text { Copper (mg/kg) (Mean } \\
\pm \text { STD })\end{array}$ \\
\hline $\begin{array}{c}\text { Garden } \\
\text { rocket } \\
\text { (Eruca } \\
\text { sativa) }\end{array}$ & $2938.57 \pm 902.23$ & $98.67 \pm 31.07$ & $7.56 \pm 1.99$ & $1.17 \pm 0.63$ \\
\hline $\begin{array}{c}\text { Parsley } \\
\text { (Apium } \\
\text { petroselin } \\
\text { um) }\end{array}$ & $2415.71 \pm 516.81$ & $70.93 \pm 16.62$ & $6.35 \pm 2.15$ & $1.36 \pm 0.41$ \\
\hline $\begin{array}{c}\text { Tomato } \\
\text { (Lycopersi } \\
\text { con } \\
\text { esculentu } \\
\text { m Mill.) }\end{array}$ & $2178.21 \pm 347.83$ & $38.66 \pm 9.95$ & $6.40 \pm 1.27$ & $1.51 \pm .40$ \\
\hline $\begin{array}{c}\text { Snake } \\
\text { cucumber } \\
\text { (Cucumis } \\
\text { melo var. } \\
\text { flexuosus) }\end{array}$ & $1791.79 \pm 629.19$ & $32.23 \pm 7.05$ & $6.85 \pm 1.93$ & $1.32 \pm 0.89$ \\
\hline $\begin{array}{l}\text { Cucumber } \\
\text { (Cucumis } \\
\text { sativus) }\end{array}$ & $1719 \pm 855.22$ & $24.05 \pm 7.68$ & $6.61 \pm 1.64$ & $0.95 \pm 0.65$ \\
\hline $\begin{array}{c}\text { Carrot } \\
\text { (Daucus }\end{array}$ & $1299.64 \pm 582.79$ & $31.37 \pm 10.65$ & $7.13 \pm 2.31$ & $3.54 \pm 3.78$ \\
\hline
\end{tabular}




\begin{tabular}{|c|c|c|c|c|}
\hline $\begin{array}{c}\text { carota } \\
\text { subsp. } \\
\text { Sativus })\end{array}$ & & & & \\
\hline $\begin{array}{c}\text { Bell } \\
\text { pepper } \\
\left(\begin{array}{c}\text { Capsicum } \\
\text { annuum })\end{array}\right.\end{array}$ & $1136.07 \pm 467.92$ & $32.64 \pm 16.96$ & $6.01 \pm 2.27$ & $1.09 \pm 0.50$ \\
\hline
\end{tabular}

Table 2:-Comparisons of the moisture (\%), Ash content $\%$ and organic content $\%$ between the different types of studied vegetables

\begin{tabular}{|c|c|c|c|c|}
\hline $\begin{array}{c}\text { Vegetable } \\
\text { s }\end{array}$ & $\begin{array}{c}\text { Mg (mg/kg) (Mean } \pm \\
\text { STD) }\end{array}$ & $\begin{array}{c}\text { Iron }(\mathrm{mg} / \mathrm{kg})(\text { Mean } \\
\pm \text { STD })\end{array}$ & $\begin{array}{c}\text { Zinc (mg/kg) (Mean } \\
\pm \text { STD })\end{array}$ & $\begin{array}{c}\text { Copper (mg/kg) (Mean } \\
\pm \text { STD) }\end{array}$ \\
\hline $\begin{array}{c}\text { Garden } \\
\text { rocket } \\
\text { (Eruca } \\
\text { sativa) }\end{array}$ & $2938.57 \pm 902.23$ & $98.67 \pm 31.07$ & $7.56 \pm 1.99$ & $1.17 \pm 0.63$ \\
\hline $\begin{array}{c}\text { Parsley } \\
\text { (Apium } \\
\text { petroselin } \\
\text { um) }\end{array}$ & $2415.71 \pm 516.81$ & $70.93 \pm 16.62$ & $6.35 \pm 2.15$ & $1.36 \pm 0.41$ \\
\hline $\begin{array}{c}\text { Tomato } \\
\text { (Lycopersi } \\
\text { con } \\
\text { esculentu } \\
\text { m Mill.) }\end{array}$ & $2178.21 \pm 347.83$ & $38.66 \pm 9.95$ & $6.40 \pm 1.27$ & $1.51 \pm .40$ \\
\hline $\begin{array}{c}\text { Snake } \\
\text { cucumber } \\
\text { (Cucumis } \\
\text { melo var. } \\
\text { flexuosus) }\end{array}$ & $1791.79 \pm 629.19$ & $32.23 \pm 7.05$ & $6.85 \pm 1.93$ & $1.32 \pm 0.89$ \\
\hline $\begin{array}{c}\text { Cucumber } \\
\text { (Cucumis } \\
\text { sativus) }\end{array}$ & $1719 \pm 855.22$ & $24.05 \pm 7.68$ & $6.61 \pm 1.64$ & $0.95 \pm 0.65$ \\
\hline $\begin{array}{c}\text { Carrot } \\
\text { (Daucus } \\
\text { carota } \\
\text { subsp. } \\
\text { Sativus) } \\
\end{array}$ & $1299.64 \pm 582.79$ & $31.37 \pm 10.65$ & $7.13 \pm 2.31$ & $3.54 \pm 3.78$ \\
\hline $\begin{array}{c}\text { Bell } \\
\text { pepper } \\
\text { (Capsicum } \\
\text { annuum) }\end{array}$ & $1136.07 \pm 467.92$ & $32.64 \pm 16.96$ & $6.01 \pm 2.27$ & $1.09 \pm 0.50$ \\
\hline
\end{tabular}

\section{References:-}

1. AOAC International, (2007).Official methods of analysis, 18th edn., Current through revision 2, 2007 (On-line).

2. Auld D (2005) Zinc enzymes. In: King RB (ed) Encyclopedia of inorganic chemistry. Wiley, Chichester, pp 5885-5927

3. Barlas, N. T., Irget, M. E., \& Tepecik, M. (2011). Mineral content of the rocket plant (Eruca sativa). African Journal of Biotechnology, 10(64), 14080-14082.

4. Crichton, R. (2016). Iron metabolism: from molecular mechanisms to clinical consequences. John Wiley \& Sons.

5. Dictionary, C. (2008). Cambridge Advanced Learner's Dictionary.

6. Dogar, M. A., \& Van Hai, T. (1980).Effect of P, N and HCO3-Levels in the Nutrient Solution on Rate of Zn Absorption by Rice Roots and Zn Content in Plants.Zeitschrift fuer Pflanzenphysiologie, 98(3), 203-212.

7. Edward D. and Harris, (2013). Copper, Biological Functions. In Encyclopedia of Metalloproteins (pp. 718).Springer New York. 
8. Eissa, M. W., \& AL-Ahmary, K. M. (2005).Determination of Some Elements in Local Food Products in Kingdom of Saudi Arabia.Science, 17(1).

9. Forster, H. (1980). Einfluß von unterschiedlich starkem Magnesiummangel bei Gerste auf den Kornertrag und seine Komponenten. Zeitschrift für Pflanzenernährung und Bodenkunde, 143(6), 627-637.

10. Gregory, E. Welbaum, (2015).Vegetable Production and Practices. United Kingdom. CABI.

11. Gregory, E. Welbaum, (2015).Vegetable Production and Practices. United Kingdom. CABI.

12. Heldt, H. W. (2011). Plant biochemistry-/Hans-Walter Heldt, Birgit Piechulla; in cooperation with Fiona Heldt.

13.Hussein, L., \& Bruggeman, J. (1997). Zinc analysis of Egyptian foods and estimated daily intakes among an urban population group. Food chemistry, 58(4), 391-398.

14. Ilelaboye, N. O. A., \& Pikuda, O. O. (2009).Determination of minerals and anti-nutritional factors of some lesser-known crop seeds.Pakistan Journal of Nutrition, 8(10), 1652-1656.

15.Li, Y. V. (2012). Zinc overload in stroke. In Metal Ion in Stroke (pp. 167-189).Springer New York.

16.Lin, M. S., \& Kao, C. H. (1990). Senescence of rice leaves XXIII. Changes of Zn2+-dependent acid inorganic pyrophosphatase.Journal of plant physiology, 137(1), 41-45.

17.Little, W., Fowler, H. W., Coulson, J., Onions, C. T., \& Friedrichsen, G. W. S. (1992). The shorter Oxford English dictionary on historical principles.

18. Marschner, H. (2011). Marschner's mineral nutrition of higher plants.Academic press.

19. Miller, G. W., Pushnik, J. C., \& Welkie, G. W. (1984). Iron chlorosis, a world wide problem, the relation of chlorophyll biosynthesis to iron. Journal of Plant Nutrition, 7(1-5), 1-22.

20. Mohammed, M.A., 2005. Economics Production of Tomato in Khartoum State. M.Sc. Thesis, Faculty of Agricultural Studies, Sudan University of Science and Technology, Sudan

21. Muchukuri, K., Kungu, N., Ayaga, G.O. and Gachini, G.N. (2004). Training Notes for KARI laboratory staff on soil and plant analysis course held at NARL Kabete (unpublished). Pp 62-74, 82-88.

22. Onianwa, P. C., Adeyemo, A. O., Idowu, O. E., \& Ogabiela, E. E. (2001). Copper and zinc contents of Nigerian foods and estimates of the adult dietary intakes.Food chemistry, 72(1), 89-95.

23.Parveen, Z., Khuhro, M. I., \& Rafiq, N. (2003). Market basket survey for lead, cadmium, copper, chromium, nickel, and zinc in fruits and vegetables. Bulletin of environmental contamination and toxicology, 71(6), 12601264.

24.Prasad, A. S. (2013). Zinc deficiency. In Encyclopedia of Metalloproteins (pp. 2412-2420).Springer New York.

25. Radwan, M. A., \& Salama, A. K. (2006).Market basket survey for some heavy metals in Egyptian fruits and vegetables.Food and Chemical Toxicology, 44(8), 1273-1278.

26. Robson, A. D., \& Reuter, D. J. (1981).Diagnosis of copper deficiency and toxicity.Copper in soils and plants. pp. 287-312. Academic Press, London and Orlando.

27.Singh, B.R. and Steinnes, E. )1994(.Soil and water contamination by heavy metals.In Soil Processes and Water Quality.Advances in Soil Science. R. Lal and B.A. Stewart, (eds.). Lewis Publishers, CRC Press, Inc., Boca Raton, Florida. pp. 233-270.

28. Smith, G. S., Cornforth, S., and Henderson, H. V. (1984). Iron requirements of C3 and C4 plants. New phytologist, 97(4), 543-556.

29. Vassilev, A., Nikolova, A., Koleva, L., \& Lidon, F. (2011).Effects of excess Zn on growth and photosynthetic performance of young bean plants.Journal of phytology, 3(6).

30. Welch, R. M., \& Shuman, L. (1995). Micronutrient nutrition of plants.Critical Reviews in plant sciences, 14(1), 49-82.

31. WHo, J., \& World Health Organization. (2003). Diet, nutrition and the prevention of chronic diseases: report of a joint WH.

32. Wolf, F. I., \& Trapani, V. (2008).Cell (patho) physiology of magnesium.Clinical science, 114(1), 27-35.

33. Yamauchi, M. (1989). Rice bronzing in Nigeria caused by nutrient imbalances and its control by potassium sulfate application. Plant and Soil, 117(2), 275-286.

34.Zaroug, M. G. (2000). Country Pasture/Forage Resouce Profiles-Sudan.Grassland and Pasture Crops, Plant Production and Protection Division, Food and Agriculture Organization of the United Nations. 